\title{
Article
}

\section{Threads, Woven Together: Negotiating the Complex Intersectionality of Writing Centres}

\author{
Srividya Natarajan \\ King's University College at Western University \\ Patrick Morley \\ King's University College at Western University
}

\section{Abstract}

The Canadian college where the authors are employed has an ethos that supports its writing centre's commitment to promoting equitable access to power, education, and employment. In recent years, one result of this ongoing commitment has been the hiring of tutoring staff with diverse identities and life-situations (in terms of race and ethnicity, dis/ability, and sexuality). The authors of this paper, one of them the director of the centre and the other a consultant at the centre, draw on their personal experiences and observations to discuss one unexpected consequence of the push for inclusivity: tutees sometimes struggle to process the demand for social literacy and cross-cultural competence placed on them during encounters with tutors who have non-mainstream identities or affiliations. Seeking to understand the pedagogic and ethical complexities of encounters specifically between tutees and racialized tutors, we propose that responsibility for effecting positive social change-for building a "brave space" - through patient relationship-building and commitment to critical consciousness be allocated to the writer and the tutor, but above all to the writing centre as a collective.

Keywords: Writing centre; social justice; intersectionality; cultural competence; pedagogy of discomfort; brave space 
Volume 30, 2020

http://journals.sfu.ca/cjsdw

\section{Introduction}

I tell my students, "When you get these jobs that you have been so brilliantly trained for, just remember that your real job is that if you are free, you need to free somebody else. If you have some power, then your job is to empower somebody else. This is not just a grab-bag candy game."

--Toni Morrison, in an interview by Pam Houston (2003)

The scramble to rationalize post-secondary education in accordance with neoliberal values and government priorities has popularized the catchphrase "academic differentiation": the idea that institutions should develop areas they already specialize in, minimizing disciplinary overlap, so that, as $\mathrm{On}_{\text {- }}$ tario's Differentiation Policy Framework (2013) puts it, "collectively they offer the maximum choice, flexibility, and quality experience to Ontario students" (p. 10). For smaller colleges affiliated to large, multi-faculty universities, "differentiation" often means offering programs complementary to, rather than in competition with, programs offered at the constituent university.

The authors of this paper (Vidya and Patrick) work at the writing centre of an affiliated college that enrols around 3,500 students each year, including around 600 international students. Asserting its denominational and progressive identity, the college differentiates itself by promoting 'soft' social sciences-disciplines such as Social Justice and Peace Studies, Disability Studies, and Social Workthat are not available at the parent institution. Though Canadian universities are increasingly saturated with competitive, individualist values (Giroux, 2014; Watermeyer \& Olssen, 2016), paradoxically, neoliberal institutional branding has opened a pathway for social justice-oriented studies and initiatives at our college. We in the writing centre, therefore, find ourselves in a strong position to adopt pedagogies and practices, such as anti-oppressive tutoring frameworks and inclusive hiring, that foster educational equity and access.

As a result of our intentionally inclusive hiring policy, our writing centre's staff roster has included, in the last three years, tutors of colour (including international student tutors who use English mainly for academic purposes), tutors who identify as LGBTQ+, tutors with disabilities, and tutors from working-class backgrounds. Our starting point in this article is our personal experience of being troubled, even as we sought to make the space "safe" for its users, by one particular unexpected consequence of our push for inclusivity: some writers (i.e., tutees) struggled to engage with tutors who had non-mainstream identities or affiliations, and this occasionally led to sessions fraught with 
Volume 30, 2020

http://journals.sfu.ca/cjsdw

unspoken tensions.

Limiting the scope of our discussion, first to encounters specifically between tutees and (negatively) racialized tutors and, second, to strategies focused on attitudinal change, we try to answer the following question: how can we create an environment whose intellectual and affective elements allow the writing centre's pedagogic projects to be effectively and comfortably carried forward by tutors with diverse identities and backgrounds? In response, we posit that we must ask racialized tutors to assume responsibility for wide reading in targeted preparation for such encounters, for open discussions, for empathetic guidance of the tutee, and for commitment to relationship-building. We further posit that, reaching for a new interpretation of the familiar writing centre dictum "develop the writer, not the writing," we must encourage the tutee to take responsibility for eradicating their own biases. Ultimately, however, the writing centre must, as a collective, accept the lion's share of the ethical obligation to prepare the ground for positive social change, and to support both tutors and writers as they navigate challenging or polarizing ideas and relationships. We suggest that this obligation can be met through constant collective vigilance and "looking out for each other," through the articulation of a clear anti-oppressive tutoring philosophy, through the careful balancing of relationship-building with calling to account, and through an acceptance of the long learning curves that result in enduring social change.

\section{Tutor Diversity and Tutees' Cultural Competence}

\section{Vidya}

I was hired as the director of the writing centre three years ago. In these three years, I have lost count of the number of times I have stood up to shake a centre visitor's hand or started to provide information about our services, only to realize that the visitor (student, professor, parent, or whoever) has automatically oriented themselves to one of my white colleagues, and has begun a conversation. There is a moment of awkwardness when they realize my hand is stretched out, or that my greeting has been half-uttered, and quite often, there is some embarrassed course-correction to include me. For me, these moments of strain represent more than fleeting failures in communication. Their cumulative effect has been to mark the writing centre-both the physical one in which I stand, during one of those moments, and the notional, ideal, abstract one-as a white space.

I strongly concur with Grimm's (2011) affirmation that writing centres have the "potential to be 
Volume 30, 2020

http://journals.sfu.ca/cjsdw

deeply transformative sites" if the encounters between tutors and writers from diverse backgrounds "are theorized in ways that locate communication 'problems' in the nature of diverse, rapidly changing, and competing discourse and cultural systems rather than in individual writers" (p. 90). However, much of this theorizing, to date, has assumed a situation where the tutor is white and ablebodied and the writer is marked by a minority identity. For instance, Denny (2010) powerfully problematizes a well-meaning white tutor's erasure of the written accent of a tutee from the Caribbean (pp. 120-121). Lerner (2019) uses the cautionary tale of Biswanath Halder, narrated by him in startlingly racist and ableist language, to point to the ways in which tutor whiteness and tutor authority might both encounter and create resistance in racialized tutees.

As I supervised or participated in tutoring at our writing centre, I noticed that while some tutees appear to relax or feel validated and empowered when their own identities are mirrored in those of their tutors (see Lee, 2020, p. 131), other tutees feel challenged by our diverse and non-mainstream tutors. Invited to work with tutors who look different from them, use assistive devices, or speak "with an accent," and required at short notice to display social literacy, empathy, or cross-cultural competence, some tutees feel discomfort or a sense of dissonance. This discomfort may be expressed verbally, but it is more often revealed in non-verbal behaviour that defies naming and challenging. Here is another experience that I (a woman of colour and a first-generation immigrant to Canada) have had on many occasions: when I introduce myself as the tutor with whom a tutee will work, the tutee will immediately (and no doubt inadvertently) look around to see if anyone else is available, or volunteer that they worked with a different tutor in their previous session. I have also observed other racialized tutors receiving this response, but my white colleagues have rarely been aware of it happening to me or to the other minoritized tutors. It took several iterations of this response before I was willing to validate my own perception that there was a pattern to it, and several more before I would allow myself to name it a microaggression.

Writing centre sessions, given the stress of deadlines on writers, and given conflicts over the kind of help tutees are seeking, can be tension-laden for reasons far removed from identity politics. Relying on my own experiences of sessions in which I felt that other stressors were salient, and sessions in which I felt my race was the likely issue, I will venture that what I described in the previous paragraph was an instance of a "racial microaggression." Sue et al. (2007) describe racial microaggressions as "brief and commonplace daily verbal, behavioral, and environmental indignities, whether intentional or unintentional, that communicate hostile, derogatory, or negative racial slights and 
Volume 30, 2020

http://journals.sfu.ca/cjsdw

insults to the target person or group" (p. 273). Microaggressions in the tutoring session often present as reluctance to establish eye-contact, frequent turning away towards another person in the room, unwillingness to respond to encouragement or questions, gestures of impatience (sighs, eye-rolls, drumming, shrugs), facial expressions signalling distrust or strong negative affect, and signs of embarrassment, stress, or restlessness. All this is behaviour whose signification is not transparent; its interpretation is admittedly dependent on the receiver's perception. And, as Mohamed and Beagan (2019) point out, "[t]hough those on the receiving end of microaggressions are often attuned to these experiences and have a more accurate assessment of their meaning, the failure of others to recognize it can raise self-doubt and uncertainty" (p. 339). Unlike the language used by the writer or the questions posed by the tutor, non-verbal cues generate no transcript amenable to discourse analysis. I thus base my discussion on my personal (and cumulative) experiences, observations, and intuitions, as well as on secondary research on racial bias and normative whiteness in the Canadian academic context, rather than on empirical research.

Even though the question of race and writing centres remains under-researched, there is some corroboration of my perceptions within writing centre scholarship. For example, in a case study by Lee (2020) documenting the experiences of African American writing centre employees, two tutors, Mo and Vee, "cite microaggressions they experience or observe in the writing center. Both consultants share multiple 'are you my consultant?' experiences, where they describe a non-Black consultee questioning their ability to help or guide them by asking the same question" (p. 135, emphasis in the original). Denny (2010) tells the story of an African American tutor whose authority was questioned to her face by her tutee, a Russian visiting student who was expecting to work with a white tutor (p. 32).

Zhao (2017) compares writer reactions to tutors who are native English speakers with writer reactions to tutors who are (racialized) non-native speakers of English, and observes that the cognitive dissonance and noticeable resistance triggered by an encounter with a tutor of colour occur in sessions with both white and racialized tutees. In other words, both white and non-white tutees are disconcerted when paired up with racialized tutors. What is at play here is the coding of academic spaces, especially those in which English or writing are the stock in trade, as white. Researching the experiences of non-white teachers of English in Toronto, Ramjattan notes that "in the realm of ELT [English Language Teaching,] ... expertise in English is a matter of embodiment.... [S]ince a white body signifies nativeness in English, as well as an English-speaking nation and a racialized body 
Volume 30, 2020

http://journals.sfu.ca/cjsdw

indicates the opposite... the body thus becomes a quick, visual means for students to determine who is native/qualified and non-native/unqualified" (378). Denny (2010) notes that in the American context, the paradigmatic citizen (and thus the competent academic) is both white and, importantly, a native speaker of English.

Discussing the Canadian context, Mohamed and Beagan note that "[r]acialized and Indigenous faculty [and, one may add, tutors] are 'unexpected bodies' in academia, requiring they work to ease the tensions of their presence" (p. 350). If linguistic, cultural, and rhetorical authority, or even mere competence in English, is widely identified with whiteness, it is not surprising that a tutee might feel "cheated" when asked to work with a racialized tutor. In committing to accepting guidance from a tutor, or in entering a pedagogic relationship with the tutor, the tutee is, after all, accepting-however provisionally and temporarily - the tutor's authority, and what then is the point of a tutor who, by virtue of non-whiteness, lacks authority, and cannot be trusted to offer adequate guidance?

In sum, based on the narratives and perspectives of racialized academics, it would be fair to say that writers, by and large, no matter how they themselves identify—as racialized or white, Canadian or international-still come to the writing centre expecting to sit down with competent tutors who are white, middle class, native speakers of English, and well-versed in standard language conventions. Greeted by a racialized tutor who speaks with an unfamiliar accent, some writers are visibly disconcerted or upset. Though writers can occasionally be uncooperative or impolite, in most instances their troubled/negative reactions come across as an honest struggle to process the unfamiliar-as a moment of cognitive dissonance-rather than as intentional rudeness.

So we must answer the key question: what is the ethical approach to running the session, and to employing an anti-racist framework when the tutor is racialized and the tutee is biased against racialized tutors? In our everyday writing centre encounters, it is not always easy to see one party as the transgressor and the other as the victim, or to create simple rules of fairness that will work in every instance. How do we distribute our empathy, for instance, in the case of an older PakistaniCanadian male writer who finds it next to impossible to take direction from a young female IndoCanadian tutor? How do we arbitrate in the case of a first-generation white writer with a learning disability who is frustrated with the help offered by a Black international student tutor from the Bahamas? As Mundy and Sugerman (2017) observe, the markers of identity in writing centre staff carry the effects of intersectionality, in that they are not neatly "organized or stratified, but ... rather are 
Volume 30, 2020

http://journals.sfu.ca/cjsdw

fluid and move individuals from positions of authority to marginality, given time, place, and context" (Multicultural Competence section, para. 4). When a writer displays discomfort or resistance while interacting with a tutor marked by race (and by gender, class, or disability intersecting with race), how can we craft a response that takes the writer's own location, predicament, and need for safety seriously, yet does not ask the minoritized tutor to passively accept microaggressive behaviour or disrespect in the name of "customer service"?

One way to begin answering this complex question is to ask a simpler one: whose responsibility is it to address the awkwardness or "communication problems" sometimes generated by cross-cultural encounters in the writing centre?

\section{The Tutor's Responsibility: Preparation for Compassion and Resilience}

\section{Vidya}

Writing centre staff must always respect the narrow and immediate purpose (the reviewing or discussion of their papers) that brings writers to us. Indeed, if we accept Carino's (2003) argument that the tutor often, by virtue of official role and academic advantage, has significant power in the tutorwriter relationship, then the complex intersectionality of the encounter between the writer who bears the privileges of race or able-bodiedness and the tutor with a minority identity must be acknowledged and understood. The fact that power is not concentrated in a simple way in the hands of either the tutor or the writer inevitably complicates the ethical challenge. The tutor's acknowledgement of her situational power could be a good thing. It could direct her to accept the responsibility to remain patient. She could soften her expectation of attitudinal change and display "strategic empathy" (Zembylas, 2015, p. 172) towards the writer. Indeed, if the microaggression that resulted from the writer's moment of cognitive dissonance were mild and transitory, the tutor's willingness to ignore it could spark a pleasant one-off discussion, or even build trust and lay the foundation of a solid long-term writing partnership. As Suhr-Sytsma and Brown (2011) note, the tutor's adoption of a "tone of respect, sensitivity, and understanding can increase receptivity and bolster an atmosphere of peer learning," and "supportive comments, shared experiences, and humor” can “build rapport, often leading to productive dialogue” (p. 44).

On the other hand, as Sue (2010) has noted, while "racism in the form of racial microaggressions may seem trivial, harmless, and innocent enough... their impact may create maximum harm to the 
Volume 30, 2020

http://journals.sfu.ca/cjsdw

individual" (p. 139). Consistently being at the receiving end of microaggressive behaviour has cumulatively damaging psychological effects. It seems unfair that the tutor should bear this burden of overlooking disrespect, however mild, indefinitely (or even temporarily, if the aggression escalates).

In her keynote address to the International Writing Centres Association's annual conference in Chicago in 2017, Neisha-Anne Green stunningly captured the isolation of being a Black female writing centre director, and handed the responsibility for anti-racist work back to white colleagues, saying, "I've long decided I was giving you back this problem of racism, cause it isn't of my invention, or that of my foreparents" (2018, p. 31). While all parties involved in a cross-racial encounter must inevitably take responsibility for anti-racist work, and while Green is not saying that writers, whatever their racial status, should be tasked with the largest share of this work, her statement raises the question of the unjust psychic cost to the minoritized employee of feeling compelled to accept everyday discourtesies and slights.

One way of offsetting this cost, of building psychic and intellectual resources that may contribute to critical understanding and resilience, is to invest in tutor preparation. Our college's stated commitment to diversity, social justice, and accessibility guided my colleagues and me as we embarked three years ago on the process of re-visioning the centre's pedagogy, everyday practices, policies, and philosophy. Our tutor preparation process, accordingly, has been responsive to:

- our reading and discussion of writing centre scholarship that emphasizes the importance of antioppressive practice (for instance, Geller, Eodice, Condon, Carroll, \& Boquet, 2007; Greenfield \& Rowan, 2011);

- advice and input from students and colleagues from diverse ethnic backgrounds, students with disabilities, Indigenous students, and advisors like Liz Akiwenzie, an Ojibway/Oneida Knowledge-Keeper; and

- theoretical frameworks emerging out of disciplines like Social Justice and Peace Studies, Disability Studies, Thanatology, Social Work, and Political Science, with whose instructors we have built solid and fruitful collaborations.

Our tutor preparation modules introduce our staff to strategies for interpersonal communication, empathy-building, and conflict resolution using role-play, to tutoring philosophies that are both 
Volume 30, 2020

http://journals.sfu.ca/cjsdw

individualist and collectivist or collaborative in their inspiration, and to tutoring pedagogies that accord value to both directive and non-directive strategies. Importantly, however, we discuss tutoring strategies not as decontextualized techniques or only in the context of scenarios ("Your last appointment of the day is with an ESL student who is upset that you won't proofread..."), but rather in the context of the contentious, troubled, colonial history and politics of writing studies and writing centres, the exclusionary racism of standard language ideologies, and the politics of disability. We consider what moral, cultural, and linguistic assumptions might be made in a throwaway whispered post-session conversation about, say, how that "ESL student plagiarized a whole paragraph," or in session notes about how a writer was "encouraged to substitute inappropriate slang words with more academic language," and the ethnocentrism, rigid universalism, or ignorance about Black English Vernacular those assumptions, in turn, might spring from. During the preparation sessions, tutor diversity leads to respectful and genuinely illuminating conversations between tutors-conversations that are not only about tutoring but also about identity, academic norms, unconscious bias, and systemic inequities.

\section{The Writer's Responsibility: The Building of Brave Spaces}

\section{Patrick}

What if, instead of politely smoothing over the awkwardness of encounters between tutoring session participants from disparate cultures, we brought it out into the open? Resisting the pressure to make the space of the writing centre "safe" in an uncomplicated way for the writer, we could invite them to accept the risk of an encounter with a selfhood radically different from their own; with a foreign accent, a new way of using assistive technology, or an unfamiliar way of approaching a topic. We could challenge the writer to think through how power and knowledge intersect with identity. Invoking an idea that, among others, Arao and Clemens (2013) have elaborated, we could walk with the writer into the "brave" space of pedagogic relations: a space in which systemic social inequity is acknowledged and addressed, rather than obscured. In thus expecting that during the session, writers will work not only on their writing tasks, but also on their capacity to accept and be comfortable with people of diverse backgrounds and identities, and perhaps even to develop a critical consciousness regarding social relations, we reach for a richer, if more exacting, interpretation of the familiar dictum that at writing centres, "[o]ur job is to produce better writers, not better writing" (North, 1984, p. 438). 
Volume 30, 2020

http://journals.sfu.ca/cjsdw

Setting a higher bar for respectful cross-cultural interaction, far from being an imposition on writers, can, in fact, be vastly beneficial to them. Developing a capacity for getting along with Others of all kinds makes good sense for future citizens of increasingly multicultural societies. Grimm (2011) points to one of the educational obligations of the university-an obligation that is arguably highly relevant in Canada, even though she is referencing America: “Today, regardless of a university's reputation as conservative or progressive, learning to learn and communicate in diverse global environments is a primary educational concern. Global environments are linguistically, culturally, and racially complex" (p. 80). The pedagogic goal of fostering effective collaboration and communication across difference and disparity can act as a counterpoint to what Watermeyer and Olssen (2016) perceive as "an omnipresence of competitiveness" in the neoliberal university (p. 202). It can help resist "the ideologies of neoliberalism and whiteness" that, as Henry et al. (2007) argue, "structure the [university's] articulation and evaluation of merit, democracy, and diversity" (p. 302). And it may be of critical value in today's contentious political climate, where the increasing legitimization of populist fear-mongering about diversity is beginning to poison the North American educational environment even as it relentlessly features on social media platforms and seeps into every aspect of civic life.

On the face of it, tutors in writing centres should feel justified in expecting writers to meet them halfway in a journey towards mutual acceptance and understanding. The white male writer, for instance, might legitimately be asked to critically examine the deep social conditioning and pervasive privilege that is the hidden source of the dismay he feels when he discovers that he has been paired up with a female tutor of colour. While it makes sense to urge that writer to become a citizen of the world through self-examination, it is conceivable that the labour of improving the writing cannot go smoothly if the writer is simultaneously making a massive cognitive investment in admitting and correcting his cultural bias. In fact, the writer's negative response to feeling judged-his discomfortis likely to block both attitudinal change and rhetorical progress. As Applebaum (2017) suggests, "discomfort can be transformative only under qualified conditions and ...too much discomfort may be counter-productive to learning" (p. 863). Instead of encouraging the writer's development both in writing and in cultural competence, the session that drives the moral lesson home too hard can fail to deliver the help he has sought, cut off the potential relationship that might have been built with him, and be unproductive for everyone, including the tutor and the writing centre as a collective entity. So then, what can one do? 
Volume 30, 2020

http://journals.sfu.ca/cjsdw

\section{The Writing Centre's Responsibility and the Pedagogy of Discomfort}

\section{Vidya}

Boler (1999) coined the phrase "pedagogy of discomfort" to describe how educators might address the negative emotions - the welling up of defensive anger, and the fear of losing identity or experiencing change-that students with privilege might contend with when asked to engage fully with the frameworks of courses that discuss anti-oppressive practice (p. xxi). Describing this pedagogy as both "an invitation to inquiry and a call to action," Boler stresses the importance of "collective witnessing" as opposed to individual self-reflection in facilitating attitudinal change (1999, p. 176). She defines "witnessing" as a fluid and dynamic act, "a process in which we do not have the luxury of seeing a static truth or fixed certainty" (p. 186).

In the writing centre, putting a pedagogy of discomfort in action would be to invite both writers and tutors to surrender their fixed and deeply habitual ideas about language, power, identity, academic success, race, class, able-bodiedness and so on, in favour of genuinely caring and open-minded attention to partners in the writing session. Acceptance of psychological risk and uncertainty, always challenging, replaces fixed convictions, and opens up the possibility of new kinds of understanding through the experience of vulnerability. As Applebaum (2017) notes, "[a] pedagogy of discomfort counters universal expectations that teachers must create comfortable environments for students and assumes that comfort can foreclose learning and obstruct change. Discomfort thus becomes synonymous with the possibility of individual and social transformation" (p. 863).

Embracing a pedagogy of discomfort in the writing centre flies in the face of the long-cherished hope of developing it into an unequivocally "safe" space. In the spirit of sincere inquiry, such a pedagogy admits that there are no universally safe spaces: ensuring some measure of safety (from dominant narratives about race, or ableism, for example) for one group or person may expose the privileges of other groups or persons to implicit critique, thus rendering the latter vulnerable. Moreover, a pedagogy of discomfort calls attention to the ever-shifting, uncertain ground of social relations as well as the dynamic and precarious quality of selves that traverse this ground. In this respect, Boler's ideas line up with those of educators who stress the need for "brave" or even "braver" (i.e., constantly evolving) spaces that support radical change more effectively than "safe" spaces, which imply a certain kind of protective stasis (Martini \& Webster, 2017). Brave spaces by definition trouble notions 
Volume 30, 2020

http://journals.sfu.ca/cjsdw

of fixed and inviolable selfhood.

However, in so far as a pedagogy of discomfort is, in Boler's words, "a call to action," it does not completely rule out the idea of creating a (strategically) safe space. In fact, such a pedagogy, thoughtfully applied in the writing centre, would educate and support the writer as they handled the risks of encounters with otherness, and as they reacted to beliefs and embodiment that seemed alien or threatening. Zembylas (2015) argues that a pedagogy of discomfort is indeed ethical if students are offered support as they contend with the negative emotions that come with admitting privilege. In suspending judgement and censure of the privileged in favour of strategic empathy and tolerancewith the minoritized tutor fully aware of the contingent value and limits of such tolerance-the pedagogy would in fact set up a fruitful dialectic between bravery and safety, between the psychological challenge of surrendering privilege to build equity and the psychological comfort of community or relationship.

What might treading this line between safety and bravery look like? To answer this, I will turn again to my own experience. I continuously remind myself that it is important not to evaluate the discomfort expressed by white tutees during sessions with me too hastily as arising from racial hostility. When I do not sense strong antagonism, I take time to "read" the discomfort, and sometimes am reasonably certain that bringing race into the open will be helpful (while in other cases I have felt it would be unproductive, a foreclosing of pedagogic opportunities). One useful early discovery was made in the course of reading a personal reflection about race that a writer (a white woman) had written for a first-year Social Work course. The reflection tracked the writer's progress from bias and ignorance to tolerance and sensitivity. The session was going very choppily, with the writer's body language projecting hostility. This went on until we came to a part of the paper that discussed her family members' racism. I said something about my own aunt in India being similarly bigoted, except that she was casteist; and about it being a good thing that open discussion of both race and caste had made bigotry less likely among the current generation. Palpably relieved, the writer came out with the reason for her embarrassment: she thought the words "race" and "racism" might be offensive to me, and she was embarrassed that I was the one reading the paper with her (she clearly did not think of "white" as a race.). Many of our centre's tutees come in with reflection papers. I learnt to say, early in the session, "It's so hard to discuss race, isn't it, especially with someone who you feel might be offended?" And I learnt to "ease the tension of my presence" by mentioning my own unconscious biases or those of my family or friends, framing them so as to foreground the potential for positive 
Volume 30, 2020

http://journals.sfu.ca/cjsdw

change and the happy discovery of more progressive thinking, rather than shame or blame.

While individual self-reflexivity on the part of the writer is valuable, and personal flexibility and strategic or provisional empathy for the writer is needed from the tutor, what is equally or perhaps more important is the consciousness that the writing centre is collectively undertaking a project. This is a project in which each employee has a part, but also a project that enfolds the writers who visit us. Grounding this project, as we take collective responsibility for developing cultural competence among tutors and writers, is an ethic that gives the building, nourishing, and sustaining of relationships precedence over the neoliberal individualism and competitive thinking-the grab-bag candy games-that increasingly characterize the university context today.

In being mindful of relationships, we are first of all guided by the counsel of Liz Akiwenzie, whom we have been "sitting with" (i.e., listening to and learning from) over the past two years. Drawing on Traditional Knowledge from her Ojibway and Oneida heritage, Akiwenzie urges us, in our roles as educators, to avoid over-privileging rules and rationality (personal communication, March 6, 2019). A caring education, in her view, would treat each student or colleague as a whole person and would provide for the nourishment of their mind, heart, spirit, and body, as well as for full recognition of their (and our) position in a web of human relationships. Younging (2018) similarly emphasizes the ethical importance of seeing ourselves embodied and embedded in relationships. He quotes the words of his colleague Glenn Rollans: "You negotiate contentious issues through authentic relationships with other people. Building relationships involves time, respect and outward indicators of respect, and people working with people, often face to face. You have to commit to all of those things" (Rollans, quoted in Younging, 2018, p. 68). Suhr-Sytsma and Brown (2011), reporting on focus groups which examined how tutors could carry forward anti-oppressive projects in the writing centre, noted that even risky, affect-laden moves in the ethical education of tutees were effective when the foundation of solid relationships had been laid: "Shan-Estelle [first name of Brown, a Black tutor]... even reported telling writers that they sounded 'like a jerk'... a move that ... seems to conflict with the strategy of using a non-combative tone. However, ...[since] they had built relationships with writers by engaging them openly and humorously, these tutors in fact showed a great deal of respectful camaraderie as they addressed oppressive language" (p. 44).

Zembylas (2015) contends that a responsible, strategic, and educative response "to discomfort or suffering and pain needs to focus on how to minimize the (inevitable) ethical violence exerted on 
Volume 30, 2020

http://journals.sfu.ca/cjsdw

students whenever an ethical norm is introduced and [on how] it takes time and effort for students to appropriate it in a 'living way"' (p. 171). In practice, in the writing centre, what would such a responsibility look like?

First of all, it would mean that all the staff actively "look out for each other." Senior and experienced staff, and staff whose gender, racial, and class identities confer power, in particular, must position themselves as active accomplices, rather than passive allies, in the quest for social justice (Green, 2018, p. 29). As accomplices, Green (2018) argues, we can play a vital role in "moving beyond alright." If "alright" in Green's formulation is read as a de facto marker of "safe," then active accompliceship - speaking up, engaging in the work of intervention, not accepting microaggression on behalf of colleagues who are its targets—combined with a responsible building of relationships with writers, would be a way of straddling safety and bravery. Without "calling out" writers in a judgmental way, every writing centre employee could take responsibility to gently and supportively pull the hidden implications of microaggressions out into the open and to address them (perhaps privately with the writer, perhaps in ways that are so folded into the tutoring itself that the lesson in cultural competence is absorbed subliminally) rather than gloss over them as if they had not happened. To echo Toni Morrison, this is the work of "freeing somebody else" and "empowering somebody else" (Houston, 2003, Section 4, para. 2). This is the embodiment of bravery where discomfort and transformation play pivotal roles in facilitating the epistemic leap that can come from compassion.

Second, taking collective responsibility or "witnessing" together would mean articulating a philosophy of tutoring that consistently relates it to anti-oppressive practice and social justice. SuhrSytsma and Brown (2011) list some of the ways in which the tutor's and the tutee's discursive choices can become the vehicle of everyday discrimination (e.g., by exoticizing or presenting stereotypes as facts). In a section of their article titled "How Tutors and Writers Can Challenge Oppression through Attention to Language," they also outline practical strategies for countering discrimination and starting writing centre dialogues about equity or bias (maintaining a non-accusatory, non-combative tone, offering counterarguments, and so on) (p. 22). Explicitly espousing such an approach during tutor preparation or in a manual, for example, could empower minoritized tutors with the feeling that they have resources and allies to call upon when needed. Guest speakers, staff meetings, and group reflections could focus, among other things, on the question of building a brave space and on the contributions each person could make to that work. 
Volume 30, 2020

http://journals.sfu.ca/cjsdw

Third, taking collective responsibility would mean that as many colleagues as possible-and especially senior colleagues-would model, at every opportunity, the balancing of relationship-building moves with moves that give writers or tutors the insights that lead them to critique their own privilege. If such an exchange has taken place successfully, and if a debriefing session is viable, the lessons to be drawn from the successful application of anti-oppressive pedagogy should be articulated right away, and discussion should be encouraged.

Finally, taking responsibility would imply developing a sort of ferocious patience. A pedagogy of discomfort is unlikely to bear fruit overnight. Part of the problem is that while it is easy to build assimilative relationships, where the colonial logic, world-view, and norms of whiteness or ableness simply "cover" all Others and invite them to "belong" by passing or merging, it is hard to build relationships that genuinely grant space for the Other's difference to flourish and to enrich the collective. Green (2018) referencing her work as tutor, coordinator and director of a writing centre, exclaims: "I realized that on my journey, I had figured out not how to fill these positions but how to fill them as myself" (p. 21). The depth of relationships in the centre should be measured by the degree to which each person can be themselves, not only in the sense of quirky individuality, but by fully embodying their cultural, linguistic, and epistemic difference from the norm.

In the words of Morcom and Freeman (2018),

[d]ecolonizing ... means coming to an understanding that diversity is a strength, but only when all communities regard one another with respect and in a spirit of equality. Within diversity, connections can be found. The Métis sash is a great exemplar for this lesson; the threads, woven together, are stronger than each single thread alone, and build beautiful fabric.... Our students must understand that they are deeply connected to this land and to one another, and that they all have roles and responsibilities they must fulfil to create a fairer society (p. 826).

A commitment to relationships is thus also an individual and collective commitment to the nurturing of difference, and to transformation over the long-term. As has been repeatedly emphasized by Indigenous philosophers, building a fairer society involves a painstaking kind of social creativity that is able to sustain itself over a long period. 
Volume 30, 2020

http://journals.sfu.ca/cjsdw

\section{Conclusion: Threads that Are both Distinct and Woven Together}

Analyzing data from Statistics Canada's 2013 Canadian Community Health Survey, Godley (2018) concluded that "[a]lmost twenty-three percent of Canadians reported having experienced at least one form of everyday discrimination in their lifetime" (p. 130). That anti-racist work is still urgently needed is amply borne out by the Race Relations in Canada 2019 report, which noted that "[d]iscrimination due to one's race is a common experience in Canada, with one in five Canadians having experienced this regularly or from time to time" (2019, p.5). Writing centres have engaged in a longrunning debate about whether they should play an assimilationist role and uphold institutional values and the social status quo, or whether they should be anti-oppressive change agents. Where we work, we have decided that writing centres are microcosms of an imperfect society and have cast a clear vote in favour of change. The present moment, which has seen political turbulence since the start of Donald Trump's presidential term in the United States, the emergence of protest movements like Idle No More, Black Lives Matter, and \#Metoo, and the re-emergence of openly white supremacist rhetoric, seems like a good moment for all of us - student tutors, contract tutors, senior staff, writing course instructors, and administrators - to individually and collectively embrace the ongoing, nevercomplete work of defining a way of being, learning, and working together that reflects critical consciousness, care for each other, and a willingness to let each thread do its unique work in the fabric.

\section{References}

Akiwenzie, L. (March 6, 2019). Personal communication.

Applebaum, B. (2017). "Comforting Discomfort as Complicity: White Fragility and the Pursuit of Invulnerability." Hypatia, 32(4), 862-875.

Arao, B., \& Clemens, K. (2013). From safe spaces to brave spaces: A new way to frame dialogue around diversity and social justice. In L. Landreman (Ed.), The art of effective facilitation: Reflections from social justice educators (pp. 135- 150). Sterling, VA: Stylus Publishing.

Boler, M. (1999). Feeling power: Emotions and education. New York: Routledge. 
Volume 30, 2020

http://journals.sfu.ca/cjsdw

Carino, P. (2003). Power and authority in the Writing Centre. In M.A. Pemberton, \& Kinkead, J.A. (Ed.) The center will hold: Critical perspectives on Writing Center scholarship. Logan, Utah: Utah State University Press, 96-113.

Denny, Harry. (2010). Facing the Center: Toward an Identity Politics of One-to-One Mentoring. Utah State University Press.

Geller, A. E., Eodice, M., Condon, F., Carroll, M., Boquet, E.H. (2007). The everyday writing center: A community of practice. Logan, Utah: Utah State University Press.

Giroux, H. A. (2014). Neoliberalism's war on higher education. Toronto: Between the Lines.

Godley, J. (2018). Everyday discrimination in Canada: Prevalence and patterns. Canadian Journal of Sociology (Online), 43(2), 111-142. Retrieved from

\section{http://search.proquest.com/docview/2083618675/}

Green, N. (2018). Moving beyond alright: And the emotional toll of this, my life matters too, in the Writing Center work. The Writing Center Journal, 37(1), 15-34.

Greenfield, L., \& Rowan, K. (Eds.). (2011). Writing centers and the new racism: A call for sustainable dialogue and change. Logan, Utah: Utah State University Press.

Grimm, N. Retheorizing Writing Center work to transform a system of advantage based on race. In Greenfield, L. \& Rowan, K. (Eds.). Writing Centers and the new racism: A call for sustainable dialogue and change (pp. 75-100). Logan, Utah: Utah State University Press.

Henry, F., et al. (2017). Race, racialization and Indigeneity in Canadian universities. Race Ethnicity and Education, 20(3), 300-314. DOI: 10.1080/13613324.2016.1260226

Houston, P. The truest eye: Interview with Toni Morrison. O: The Oprah Magazine. November 2003. Retrieved from http://www.oprah.com/omagazine/toni-morrison-talks-love/4

Lee, K. (2020). Black in the Writing Center: Race, representation, and the post-racial lie. In Ed. Essid, J. \&. McTague, B. (Eds.). Writing Centers at the Center of Change. 1st ed. (pp. 129-139). Routledge. DOI: $10.4324 / 9780429425158-7$ 
Volume 30, 2020

http://journals.sfu.ca/cjsdw

Lerner, N. (2019). Resilience and Resistance in Writing Center Theory and Practice. Pedagogy, 19(2), 195-208. DOI: $10.1215 / 15314200-7295866$

Martini, R.H. \& Webster, T. (2017). Writing Centers as brave/r spaces: a special issue introduction. The Peer Review, 1(2). Retrieved from http://thepeerreview-iwca.org

Mohamed, T., \& Beagan, B. (2019). "Strange faces" in the academy: experiences of racialized and Indigenous faculty in Canadian universities. Race Ethnicity and Education, 22(3), 338-354. DOI: $\underline{10.1080 / 13613324.2018 .1511532}$

Morcom, L., \& Freeman, K. (2018). Niinwi-Kiinwa-Kiinwi: Building non-Indigenous allies in education through Indigenous pedagogy. Canadian Journal of Education, 41(3), 808-833.

Mundy, R. \& Sugerman R. (2017). “What can you possibly know about my experience?”: Toward a practice of self-reflection and multicultural competence. The Peer Review, 1(2). Retrieved from http://thepeerreview-iwca.org

North, S. M. (1984). The idea of a writing center. College English, 46(5), 433-446. Retrieved from http://www.jstor.org/stable/377047

Ontario's Differentiation Policy Framework for Postsecondary Education. (2013). Retrieved from http://www.tcu.gov.on.ca

Race relations in Canada (2019). Environics Institute and Canadian Foundation for Race Relations. Retrieved from https://www.environicsinstitute.org

Ramjattan, V. (2019). Racist nativist microaggressions and the professional resistance of racialized English language teachers in Toronto. Race Ethnicity and Education, 22(3), 374-390. Retrieved from https://doi.org/10.1080/13613324.2017.1377171

Sue, D.W. Microaggressions in everyday life: Race, gender, and sexual orientation. John Wiley \& Sons, 2010. ProQuest Ebook Central.

Sue, D., Capodilupo, C., Torino, G., Bucceri, J., Holder, A., Nadal, K., \& Esquilin, M. (2007). Racial microaggressions in everyday life: Implications for clinical practice. American Psychologist, 62(4), 271-286. DOI: 10.1037/0003-066X.62.4.271 
Volume 30, 2020

http://journals.sfu.ca/cjsdw

Suhr-Sytsma, M., \& Brown, S. (2011). Theory in/to Practice: Addressing the Everyday Language of Oppression in the Writing Center. Writing Center Journal, 31(2), 13-49.

Watermeyer, R. \& Olssen, M. (2016). "'Excellence' and exclusion: The individual costs of institutional competitiveness." Minerva, 54(2), 201-218.

Younging, G. (2018). Elements of Indigenous style: A guide for writing by and about Indigenous peoples. Edmonton, Alberta: Brush Education.

Zembylas, M. (2015). 'Pedagogy of discomfort' and its ethical implications: The tensions of ethical violence in social justice education. Ethics and Education, 10(2), 163-174. DOI:

$10.1080 / 17449642.2015 .1039274$

Zhao, Y. (2017). Student interactions with a native speaker tutor and a nonnative speaker tutor at an American Writing Center. The Writing Center Journal, 36(2), 57-87. 